\title{
The Role of Leadership Skills of High School Principals in Their Knowledge Management Process Competencies
}

\author{
Betül Balkar (Corresponding author) \\ Department of Educational Sciences, Gaziantep University \\ 27310, Gaziantep, Turkey \\ Tel: 90-505-542-7043Ｅ-mail: b.balkar@gmail.com \\ Sevilay Şahin \\ Department of Educational Sciences, Gaziantep University \\ 27310, Gaziantep, Turkey \\ Tel: 90-543-218-2616Ｅ-mail: ssahin@gantep.edu.tr
}

Received: Feb. 22, 2015 Accepted: May 30, 2015 Published: August 1, 2015

doi:10.5296/jse.v5i3.7631 URL: http://dx.doi.org/10.5296/jse.v5i3.7631

This article arose from a doctoral dissertation of Betül Balkar, which was titled "The role of leadership skills of high school principals in knowledge management process competencies" and completed at the University of Gaziantep, Institute of Social Sciences, Gaziantep, Turkey.

\begin{abstract}
School principals play an important role in assisting educational institutions in achieving knowledge and gaining knowledge management competence and hence, as a real knowledge organization, in meeting the needs of the age. In order to realize knowledge management, principals should take an active role both as knowledge managers and leaders. The aim of this study was to examine the extent to which leadership skills of high school principals predicted their knowledge management process competencies. In the context of this purpose, the study also aimed at investigating the relationships between principals' leadership skills and their knowledge management competencies. The sample of the study realized in a relational screening model was comprised of 573 high school teachers working in Adana province of
\end{abstract}


Turkey. The surveying method was utilized for data collection and the data obtained were statistically analyzed. The results of the study suggest that there is a statistically significant relationship between principals' knowledge management competencies and their leadership skills and that the high school principals' leadership skills are a predictor of their knowledge management process competencies. The findings of the study emphasize applicability of knowledge management at schools from a social perspective and point out that leadership of the school principal is a facilitator factor to carry out knowledge management processes at schools.

Keywords: Knowledge management process competencies, Leadership skills, High school principals, Schools 


\section{Introduction}

Having true and up-to-date knowledge and managing this knowledge have become a necessity in recent years for all organizations operating in various fields. The developments in our era have made the application of knowledge management inevitable. How much knowledge management is realized and what kind of studies will be performed depend on the quality of the institutions where knowledge management is utilized. Of course, what knowledge means to institutions and the dimension of the benefits that is provided by knowledge are the determinants that shape knowledge management practices and a running knowledge of management processes. According to Tranfield et al. (2003, p. 46), knowledge management is;

the process by which the capacity to act is facilitated or enhanced, matching knowledge sources to knowledge needs, using performative competencies which privilege the flow and sharing of knowledge over simple custody, and which is value rated by its contextual efficacy.

Knowledge management is intensely structured around human/social and/or system/technology oriented point of views (Santo, 2005). Regarding knowledge management, Turner and Minonne (2010) mentioned about the existence of human-oriented and system-oriented knowledge management practices. Knowledge management should primarily cover human factors. Many organizations tend to use high quality technology without motivating their employees in using the new systems. It would be more suitable to initiate the process by using a human-oriented approach, which is a pre-requisite in the application of a system-oriented approach if for an organization effectiveness precedes efficiency. Since the usage of knowledge depends on human effort it can be said that the knowledge management process rather depends on the human factor. Training and promoting organization members on the share of knowledge are provisions necessary for knowledge management (Pimentel \& Albino, 2010). The knowledge is related to attributing a meaning to an event or an experience. Attributing a meaning to events or experiences, however, is related to interpretation processes based on personal background and past experiences. This process that causes knowledge generation requires human participation (Rocha et al., 2008).

Executives of organizations have important roles in the application of knowledge management. Hedlund (1994) expressed that the role of senior management in knowledge management has a catalyst effect. Naturally, the executives should have various competencies to fulfil the knowledge manager role. Within this process, the executives should pay attention to developing knowledge creation and management competencies (Chadha \& Kapoor, 2010). In order to manage the processes necessary to carry out knowledge management, the executives should have knowledge management process competencies. These contain the skills and behaviors needed by the executives of organizations in performing knowledge management. Thus, the executives should have skills in assisting knowledge management applications and exhibiting necessary attitudes. Some of these competencies are related to administrative issues whereas some are related to social issues needed in accomplishing administrative requirements.

The principals' knowledge management competencies can be observed by attitudes exhibiting 
in knowledge management processes. There are number of classifications of knowledge management processes/activities. Davenport and Völpel (2001, p. 217) stated the knowledge management processes as “create, capture/store, refine, distribute, use, monitor". Bhatt (2001) discussed knowledge management processes as creation of knowledge, approval of knowledge validity, presenting the knowledge, distribution of knowledge, and application of knowledge. Zack (1999, p. 49), in the structure known as "knowledge refinery", claimed that knowledge is acquired, refined, stored, retrieved, distributed and presented, respectively.

In this study, however, knowledge management processes are discussed as knowledge creation, acquisition, storage, protection, sharing, utilization and evaluation by considering common classifications in the literature. The process of knowledge creation is a matter of the creation of new knowledge within the organization. By means of formal projects and programs within the organization, managers attempt to create new knowledge. At the end of the knowledge creation process other knowledge management activities should be used to obtain a value from the knowledge created (Nielsen, 2006). The knowledge, during the process of knowledge acquisition, is acquired from outside partners and sources (Nielsen, 2006; Rastogi, 2000). The organizations can acquire knowledge from their employees and customers. The knowledge acquired from the employees is the knowledge based on their capabilities and experiences. Knowledge acquisition from the customers depends on the relationship between the customers and the organization (Darroch, 2003). Valenzuela and his colleagues (2010, p. 113) stated that, "storage is the codification and storage process, under appropriate keeping and retrieval efficiency parameters". Having acquired the required knowledge the organization needs a database in which to store the knowledge. However, before transferring the knowledge to the database, it has to be refined by several processes. "Cleansing, labelling, indexing, sorting, abstracting, standardizing, integrating, and recategorizing" are processes which should be operated in this process (Zack, 1999, p. 49). Basically, knowledge sharing is realized by interaction between people. In order to realize knowledge sharing within the organization, the employees should be motivated on knowledge sharing and it is important to create a trust environment within the organization and to make them feel secure. The compatibility of knowledge management strategies utilized in the organization culture is also a contributing condition in the effectiveness of this process (Vorakulpipat \& Rezgui, 2008). Holsapple and Joshi (2002, p. 57) stated that "using knowledge is the activity of applying existing knowledge to generate new knowledge and/or to produce an externalization of knowledge".

Not every item of knowledge has the same importance. Therefore, one should know how to measure the value of knowledge. The applicability, usefulness and contextual function of the knowledge should be taken into account in the determination of the value of knowledge. Moreover, it should be considered whether the knowledge is critical, adequate or needed. In order for the knowledge to be critical it should create advantages for the organization in its area of activity and the timing of its use should be important. The other valuation factors to be considered are the cost of unknowing, not utilizing the current knowledge and not creating new knowledge (Bourdreau \& Couillard, 1999).

In the realization of knowledge management by organization directors, it is highly important 
for them to have process competencies as well as having leadership skills. Leadership is regarded as an important factor affecting knowledge management (Inkpen, 1996). In order to apply knowledge management, the need of knowledge management professionals, who can be change agents, requires the senior management to participate in and support this process (Koenig, 1999). Alazmi and Zairi (2003) stated that the commitment of senior management is a very important factor in knowledge management. The executives have catalyst and architect roles in the knowledge management process (Hedlund, 1994). Arntzen and Chumnumpan (2010) stated that strong leadership and the participation of executives are among the factors easing knowledge sharing. Leadership is regarded as an enabler. Thus, a leader can affect the output of an organization via knowledge management (Lee \& Choi, 2003). Having a strong individual in the position of leadership is regarded as important in knowledge creation (Inkpen, 1996).

Knowledge management and leadership capability are considered as fundamental competencies in obtaining a competitive advantage. The learning and application of knowledge management skills can be provided by means of leadership capability. The environment that the leadership capability creates provides the utilization of explicit and tacit knowledge to contribute to the targets of organizations (Babu et al., 2008). Singh (2008) stated that there is a relationship between knowledge management applications and leadership styles, and explicit and tacit types of knowledge management applications can be predicted by taking leadership styles into account. Leadership activities and the commitment of the leader to knowledge sharing contribute to the realization of the knowledge management process. Charismatic leaders acting as knowledge missionaries within an organization are an important requirement for the knowledge management process (McKenzie et al., 2001).

According to Greengard (1998) leadership must be provided to realize knowledge management. By knowing the value of knowledge management and their contributions, senior executives should contribute to the formation and development of programs and policies needed to apply knowledge management. Leadership in knowledge management covers more than supplying financial sources and spoken support. The leader should first determine the knowledge which is valuable for the organization and then decide how to realize knowledge distribution by taking the determined value into account (DeTienne et al., 2004). By considering the knowledge of the organization on production, process and customer fields, the leader should ensure working on these knowledge domains (Charney, 2005). Liebowitz (1999) reported that knowledge management strategy supported by senior leadership is also among the factors required for the application of the knowledge management process. The comprehensive knowledge management strategy should be supported morally and financially by the leadership. To realize knowledge management, leader commitment and leader acting as an educator in knowledge development should be ensured. Points that leaders should pay attention to are knowledge sharing with their employees and forming a balance between the employees' desire to work in cooperation and giving them necessary time for thinking and experiencing. Along with the leader's responsibility for providing employees with the necessary opportunities for knowledge creation, the leader is also responsible for ensuring the suitability of the created knowledge to 
the previously determined targets (Eppler \& Sukowski, 2000).

Since the educational institutions are the organizations which interact most with knowledge, it can be said that knowledge management is a process that can be realized in schools. To apply this process in schools, first the school principal should have a background in knowledge management and structure the management philosophy in this direction to execute this process (Güçlü \& Sotirofski, 2006). As in other institutions, the executives in schools have important roles in the application of knowledge management. School principals should carry out necessary actions to provide necessary infrastructure for the application of knowledge management and to gain the required skills for managing knowledge management processes in schools effectively. Exhibiting the knowledge management process capabilities by principals covering social and managerial skills and attitudes required in managing creation, acquisition, storage, sharing and application of knowledge, which are knowledge management processes, serves schools to gain the quality of knowledge organization. As in other organizations, it is not possible to realize knowledge management in schools by focusing only on technical and administrative application areas. Management also requires the application of leadership skills. Effective leadership provides a direction and purpose whereas effective management enables the realization of the purpose determined by the leadership (O'Brien et al., 2008). In this study, leadership skills of principals were considered within the scope of their practices of leading by example (model the way), encouraging a shared vision at school (inspire a shared vision), encouraging career development of teachers by fostering collaboration (enable others to act), fostering innovation and risk-taking (challenge the process) and encouraging teachers by congratulating their achievements (encourage the heart) (Kouzes \& Posner, 2001).

The school leaders should use their leadership skills consistent with their knowledge management process competencies to realize knowledge management in schools. This study in which knowledge management was discussed from a social perspective provides the investigation of the relationship between leadership skills and knowledge management processes competencies and the prediction of these competencies as well as the understanding of how leadership skills contribute to knowledge management and how they can be used in knowledge management process.

\section{The Purpose of the Study}

The purpose of this study was to examine the extent to which leadership skills of high school principals predicted their knowledge management process competencies. In the context of this primary purpose, it was also aimed at investigating the relationships between leadership skills of high school principals and their knowledge management process competencies.

\section{Problem Question}

Do high school principals' leadership skills predict their knowledge management process competencies?

\subsection{Sub-Problem}

Do high school principals' leadership skills of modelling the way, inspiring a shared vision, challenging the process, enabling personnel to act and encouraging the heart predict 


\section{Macrothink}

Journal of Studies in Education

ISSN 2162-6952

2015, Vol. 5, No. 3

knowledge management process competencies of creation, acquisition, storage and protection, sharing, utilization and the evaluation of knowledge?

\section{Method}

Relational screening model was used in the study. "Relational screening models are research models aimed at determining the existence and/or the degree of change among two or more variables" (Karasar, 2011, p. 81).

\subsection{Population and Sample}

The population of the study is comprised of the high school teachers working in Adana province of Turkey. Since high school principals' knowledge management competencies and leadership skills were investigated independent from the characteristics of high school teachers and school principals, it was not considered harmful to accept only one central town as the population. Except one school all schools in the population were incorporated into the sample of the study. The sample comprised of teachers contained 573 volunteer teachers who were determined by the random sampling method. The data related to the characteristics of high school teachers in the sample is given in Table 1.

Table 1. The demographic data belonging to the high school teachers in the sample of the study

\begin{tabular}{cccc}
\hline Demographic Characteristics & & N & \% \\
\hline Gender & Female & 260 & 45.4 \\
Age & Male & 313 & 54.6 \\
& $22-28$ & 2 & .3 \\
& $29-35$ & 118 & 20.6 \\
& $36-42$ & 225 & 39.3 \\
Professional Seniority & $43-49$ & 170 & 29.7 \\
& 50 and over & 58 & 10.1 \\
& $1-5$ & 4 & .7 \\
Length of Service in the & $6-10$ & 40 & 7.0 \\
School & $11-15$ & 188 & 32.8 \\
& $16-20$ & 194 & 33.9 \\
& 21 and over & 147 & 25.7 \\
& $1-3$ & 254 & 44.3 \\
Type of School & $4-6$ & 123 & 21.5 \\
& 7-9 & 81 & 14.1 \\
& 10 and over & 115 & 20.1 \\
& Public High School & 205 & 35.8 \\
& Anatolian High school & 199 & 34.7 \\
& Vocational/Technical High School & 138 & 24.1 \\
& Religious Vocational High School & 15 & 2.6 \\
& Fine Arts High School & 16 & 2.8 \\
\hline
\end{tabular}




\section{Macrothink}

Table 1. The demographic data belonging to the high school teachers in the sample of the study (continued)

\begin{tabular}{cccc}
\hline Demographic Characteristics & N & \% \\
\hline Educational Background & Bachelor & 535 & 93.4 \\
& Master & 35 & 6.1 \\
Major & Ph. D. & 3 & .5 \\
& Turkish Language and Literature & 100 & 17.5 \\
& History & 34 & 5.9 \\
& Geography & 31 & 5.4 \\
& Philosophy & 22 & 3.8 \\
& Foreign Language & 56 & 9.8 \\
& Religious Culture and Moral & 15 & 2.6 \\
& Knowledge & & \\
& Mathematics & 95 & 16.6 \\
& Physics & 23 & 4.0 \\
& Chemistry & 29 & 5.1 \\
& Biology & 71 & 7.2 \\
& Guidance & 4.0 \\
& Music & 1.9 \\
& Physical Education & 20 & 3.5 \\
& Visual Arts/Painting & 9 & 1.6 \\
& Vocational/Technical Courses & 54 & 9.4 \\
Information Technologies & 10 & 1.7 \\
\hline
\end{tabular}

\subsection{Data Acquisition Tools}

The data related to the school principals' knowledge management process competencies was acquired by "School Principal Knowledge Management Process Competencies" (SPKMPC) scale developed by the researcher and the data related to their leadership skills was acquired by "Leadership Practices Inventory" developed by Kouzes and Posner (2001).

As a result of exploratory factor analysis carried out in the context of the studies for the development of SPKMPC, the scale was found to be in a five-dimension structure which explains $67.736 \%$ of total variance. The SPKMPC scale is comprised of five-dimensions as creation, acquisition, storage and protection, sharing and utilization, and evaluation of knowledge and a total of 56 items. In order to validate the factors determined by the results of the exploratory factor analysis, first and second stage confirmatory factor analyses (CFA) were applied. As a result of first and second stage CFA, the first stage goodness of fit indexes was measured as $\chi^{2} / \mathrm{df}: 2.43$, CFI: .99, NFI: .98, IFI: .99, RFI: .98, NNFI: .99, RMR: .048, SRMR: .044, RMSEA: .056. The second stage goodness of fit indexes was determined as $\chi^{2}$ /df: 2.48, CFI: .99, NFI: .98, IFI: .99, RFI: .98, NNFI: .99, RMR: .051, SRMR: .047, RMSEA: .057. Hence, the five-dimension structure of the sample was validated. In the context of reliability studies, for the whole sample, the split half correlation was measured as .93 and .92 calculated by the Spearman Brown and Guttmann Split Half formula, respectively. Cronbach's Alpha Reliability Coefficient for the whole sample was .98. 
SPKMPC scale was a 1-5 Likert-type scale and accordingly scaled by "Never=1, Seldom=2, Sometimes $=3$, Usually $=4$ and Always $=5 "$.

In order to investigate school principals' leadership skills in the study the "Leadership Practices Inventory" was used, which was originally developed by Kouzes and Posner (2001) and modified by Duygulu (2007), who conducted language adaptation, validity and reliability studies. In the inventory, there are five dimensions which are named model the way, inspire a shared vision, challenge the process, enable others to act and encourage the heart. The adaptation of the Leadership Practices Inventory into Turkish together with validity and reliability studies was made by Duygulu (2007). The validity of the inventory was done by confirmatory factor analysis. It was determined in the confirmatory factor analysis that the Turkish scale is consistent with the original one and grouped under five factors. $\chi^{2}, p$, GFI, CFI, NNFI, SRMR and RMSEA were determined as 826.88, 0.25, 0.89, 1.00, 0.94, 0.05 and 0.00 , respectively. The calculated Cronbach Alpha internal coefficient of consistence was measured as .97 in the context of the Leadership Practices Inventory reliability study. Cronbach Alpha internal coefficient of consistence was measured as .86, .90, .87, .87 ad .91 for the dimensions of model the way, inspire a shared vision, challenge the process, enable others to act and encourage the heart, respectively. In this study, the Cronbach Alpha internal coefficient of consistence, Spearman-Brown Correlation, and the Guttman Split Half Correlation were measured as $.97, .92$ and .92 , respectively. The expressions in the inventory were evaluated by a 1-10 scale in the original inventory. However, in Duygulu's (2007) study, the expressions were evaluated by a 1-5 scale, according to expert opinions and by the permission taken from the authors. In this study a 1-5 scale was used (1: Scarcely ever, 2: Rarely, 3: Sometimes, 4: Often/Frequently, 5: Almost always) since Turkish version of the scale was used.

\subsection{Data Analysis}

The raw data of the study was analyzed using SPSS 14.0 software. In the analysis of the quantitative data obtained, Pearson correlation analysis, simple linear regression and stepwise multiple regression tests were applied.

\section{Findings}

5.1 The Findings on the Relationship between High School Principals' Knowledge Management Competencies and Their Leadership Skills and the Findings of Simple Regression Analysis Concerning Leadership Skills as Predictors of Knowledge Management Process Competencies

In order to investigate the relationship between high school principals' knowledge management process competencies and their leadership skills, a Pearson Correlation Analysis was performed and the results are given in Table 2 . 


\section{Macrothink}

Table 2. The results of the Pearson correlation analysis concerning the relationship between knowledge management process competencies and leadership skills

\begin{tabular}{ccc}
\hline & & Leadership skills \\
\hline Knowledge Management & $\mathrm{r}$ & .533 \\
Process Competencies & $\mathrm{p}$ & .000 \\
& $\mathrm{~N}$ & 573 \\
\hline
\end{tabular}

As Table 2 is examined, it is seen that there is a moderate, positive and statistically significant relationship between high school principals' knowledge management process competencies and their leadership skills $(\mathrm{r}=0.533, \mathrm{p}<.01)$. Therefore, it can be said that as high school principals' leadership skills develop their knowledge management process competencies will also develop.

Simple linear regression was utilized to determine how much high school principals' leadership skills predicts the knowledge management process competencies and the results are presented in Table 3.

Table 3. Simple linear regression analysis results concerning the prediction of knowledge management process competencies by leadership skills

\begin{tabular}{lccccccc}
\hline \multicolumn{7}{c}{ Predicted Variable: Knowledge Management Process Competencies } \\
\hline Variables & $\mathrm{B}$ & $\mathrm{SH}_{\mathrm{B}}$ & $\mathrm{B}$ & $\mathrm{t}$ & $\mathrm{p}$ & $\mathrm{R}$ & $\mathrm{R}^{2}$ \\
Constant & 100.427 & 7.466 & & 13.452 & .000 & & \\
Leadership Skills & .977 & .065 & .533 & 15.065 & .000 & .533 & .284 \\
\hline
\end{tabular}

As seen in Table 3 high school principals' leadership skills are statistically significant predictors of knowledge management process competencies $(\mathrm{R}=0.533, \mathrm{R} 2=0.28, \mathrm{~F}=226.96$, $\mathrm{p}<.01)$. Twenty-eight percent of total variance belonging to high school principals' knowledge management process competencies is explained by leadership skills.

5.2 The Findings Related to the Relationships between Knowledge Management Process Competencies and Leadership Skills and the Stepwise Regression Analysis Results Concerning the Leadership Skill Dimensions as the Predictors of Knowledge Management Process Competencies

Pearson Correlation Analysis was utilized to investigate the relationship between knowledge management process competencies and leadership skill dimensions. The results are given in Table 4. 
Table 4. The results of Pearson correlation analysis related to the relationship between knowledge management process competency dimensions and leadership skill dimensions

\begin{tabular}{|c|c|c|c|c|c|c|c|c|}
\hline & & 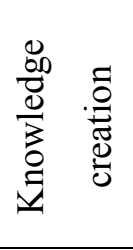 & 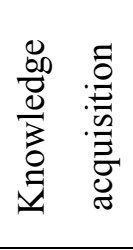 & 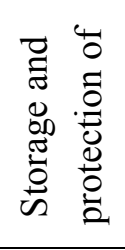 & 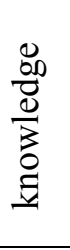 & 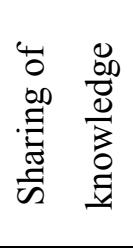 & 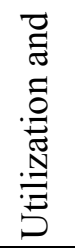 & 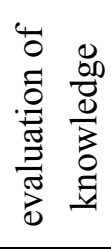 \\
\hline \multirow[t]{2}{*}{ Modelling the way } & $\mathrm{r}$ & .550 & .429 & .382 & & .461 & & .494 \\
\hline & $\mathrm{p}$ & .000 & .000 & .000 & & .000 & & .000 \\
\hline \multirow[t]{2}{*}{ Inspiring a shared vision } & $\mathrm{r}$ & .547 & .453 & .391 & & .465 & & .501 \\
\hline & $\mathrm{p}$ & .000 & .000 & .000 & & .000 & & .000 \\
\hline \multirow[t]{2}{*}{ Challenging the process } & $\mathrm{r}$ & .535 & .424 & .372 & & .490 & & .488 \\
\hline & $\mathrm{p}$ & .000 & .000 & .000 & & .000 & & .000 \\
\hline \multirow[t]{2}{*}{ Enabling personnel to act } & $\mathrm{r}$ & .538 & .431 & .366 & & .458 & & .487 \\
\hline & $\mathrm{p}$ & .000 & .000 & .000 & & .000 & & .000 \\
\hline \multirow[t]{2}{*}{ Encouraging the heart } & $\mathrm{r}$ & .482 & .385 & .292 & & .419 & & .413 \\
\hline & $\mathrm{p}$ & .000 & .000 & .000 & & .000 & & .000 \\
\hline
\end{tabular}

As seen in Table 4 there is a moderate, positive and statistically significant relationship between high school principals' leadership skills and knowledge management process competency of knowledge creation $(\mathrm{r}=0.550, \mathrm{p}<.01)$. However, there is a weak, positive and statistically significant relationships between high school principals' leadership skills and knowledge management process competencies of knowledge acquisition, knowledge storage and protection, knowledge sharing, and utilization and evaluation of knowledge $(r=0.429$, $\mathrm{p}<.01 ; \mathrm{r}=0.382, \mathrm{p}<.01 ; \mathrm{r}=0.461, \mathrm{p}<.01 ; \mathrm{r}=0.494, \mathrm{p}<.01)$. According to these results it can be said that as high school principals' leadership skills develop their knowledge management process competencies also develop.

There is a moderate, positive and statistically significant relationship between high school principals' leadership skills of inspiring a shared vision and their knowledge management process competency of the utilization and evaluation of knowledge $(r=0.547, \mathrm{p}<.01 ; \mathrm{r}=0.501$, $\mathrm{p}<.01$ ). However, there is a weak, positive and statistically significant relationship between high school principals' leadership skills of inspiring a shared vision and knowledge management process competencies of knowledge acquisition, storage and protection of knowledge $(\mathrm{r}=0.453, \mathrm{p}<.01 ; \mathrm{r}=0.391, \mathrm{p}<.01 ; \mathrm{r}=0.465, \mathrm{p}<.01)$. Accordingly, it can be said that as high school principals' leadership skills of inspiring shared vision develops management process competencies also develop.

It is seen that there is a moderate, positive and statistically significant relationship between high school principals' leadership skills of challenging the process and knowledge management process competency of knowledge creation $(\mathrm{r}=0.535, \mathrm{p}<.01)$. However, there is a weak, positive and statistically significant relationship between high school principals' 


\section{Macrothink}

leadership skills of challenging the process and knowledge management process competencies of knowledge acquisition, storage and protection of knowledge $(r=0.424$, $\mathrm{p}<.01 ; \mathrm{r}=0.372, \mathrm{p}<.01 ; \mathrm{r}=0.490, \mathrm{p}<.01 ; \mathrm{r}=0.488, \mathrm{p}<.01)$. Hence, it can be said that as high school principals' leadership skills of challenging the process develops, their management process competencies also develop.

It is seen that there is a moderate, positive and statistically significant relationship between high school principals' leadership skills of enabling personnel to act and knowledge management process competency of knowledge creation $(\mathrm{r}=0.538, \mathrm{p}<.01)$. However, there is a weak, positive and statistically significant relationship between high school principals' leadership skills of enabling personnel to act and knowledge management process competencies of knowledge acquisition, storage and protection of knowledge $(\mathrm{r}=0.431$, $\mathrm{p}<.01 ; \mathrm{r}=0.366, \mathrm{p}<.01 ; \mathrm{r}=0.458, \mathrm{p}<.01 ; \mathrm{r}=0.487, \mathrm{p}<.01)$. Hence, it can be said that as high school principals' leadership skills of enabling personnel to act develops, their management process competencies also develop.

There is a weak, positive and statistically significant relationship between high school principals' leadership skills of encouraging the heart and knowledge management process competencies of creation, acquisition, storage and protection, sharing, and utilization and evaluation of knowledge $(r=0.482, p<.01 ; r=0.385, p<.01 ; r=0.292, p<.01 ; r=0.419, p<.01$; $\mathrm{r}=0.413, \mathrm{p}<.01)$. Hence, it can be said that as high school principals' leadership skills of encouraging the heart develops, their management process competencies also develop.

In order to determine which of the leadership skill dimensions predicts significantly which of the knowledge management process competencies; stepwise multiple regression analysis was utilized. The results are presented in Table 5 to 9. In these analyses five leadership skills were used as independent variables and each of the knowledge management process competencies was taken as a dependent variable, respectively. 
Table 5. Stepwise multiple regression analysis results concerning the prediction of knowledge management process competency of creation of knowledge

\begin{tabular}{|c|c|c|c|c|c|c|c|c|c|c|}
\hline $\begin{array}{l}\overline{0} \\
\frac{0}{2}\end{array}$ & $\frac{0}{\frac{0}{0}}$ & B & $\mathrm{SH}_{\mathrm{B}}$ & $\beta$ & $\mathrm{t}$ & $\mathrm{p}$ & $\mathrm{R}$ & $\mathrm{R}^{2}$ & $\mathrm{~F}$ & $\mathrm{p}$ \\
\hline \multirow[t]{2}{*}{1} & Constant & 16.183 & 1.415 & & 11.434 & .000 & .550 & .302 & 247.405 & .000 \\
\hline & $\begin{array}{l}\text { Modelling } \\
\text { the way }\end{array}$ & .957 & .061 & .550 & 15.729 & .000 & & & & \\
\hline \multirow[t]{3}{*}{2} & Constant & 15.124 & 1.432 & & 10.562 & .000 & .564 & .318 & 132.639 & .000 \\
\hline & $\begin{array}{l}\text { Modelling } \\
\text { the way }\end{array}$ & .525 & .135 & .302 & 3.887 & .000 & & & & \\
\hline & $\begin{array}{l}\text { Inspiring a } \\
\text { shared } \\
\text { vision }\end{array}$ & .477 & .134 & .277 & 3.574 & .000 & & & & \\
\hline \multirow[t]{4}{*}{3} & Constant & 14.624 & 1.438 & & 10.166 & .000 & .570 & .325 & 91.463 & .000 \\
\hline & $\begin{array}{l}\text { Model the } \\
\text { way }\end{array}$ & .314 & .158 & .181 & 1.993 & .047 & & & & \\
\hline & $\begin{array}{l}\text { Inspiring a } \\
\text { shared } \\
\text { vision }\end{array}$ & .392 & .137 & .228 & 2.860 & .004 & & & & \\
\hline & $\begin{array}{l}\text { Enabling } \\
\text { personnel } \\
\text { to act }\end{array}$ & .319 & .125 & .189 & 2.557 & .011 & & & & \\
\hline
\end{tabular}

As seen in Table 5 three different models emerged. In the first model the leadership skills of modelling the way $(\beta=.55 ; \mathrm{t}=15.729 ; \mathrm{p}<.001)$ predicts the competency of knowledge creation. In the second model, in addition to the leadership of modelling the way $(\beta=.302$; $\mathrm{t}=3.887 ; \mathrm{p}<.001)$, inspiring a shared vision $(\beta=.277 ; \mathrm{t}=3.574 ; \mathrm{p}<.001)$ is among the variables that predict the competency of knowledge creation. In the third model, the leadership skills of modelling the way $(\beta=.181 ; \mathrm{t}=1.993 ; \mathrm{p}<.05)$, inspiring a shared vision $(\beta=.228 ; \mathrm{t}=2.860 ; \mathrm{p}<.01)$ and enabling personnel to act $(\beta=.189 ; \mathrm{t}=2.557 ; \mathrm{p}<.05)$ predict the competency of knowledge creation. As the third model, which has a relatively higher explanation rate of variance in knowledge creation than the other two models, is taken into account, the level of importance of predictor variables over explaining the competency of knowledge creation was found as inspiring a shared vision $(\beta=.228)$, enabling personnel to act $(\beta=.189)$ and modelling the way $(\beta=.181)$, respectively. The skill of modelling the way alone explains $30.2 \%$ of the competency of knowledge creation $(\mathrm{R}=.55 ; \mathrm{R} 2=.302)$. The skills of modelling the way and inspiring a shared vision together explain $31.8 \%$ of knowledge creation $(\mathrm{R}=.564 ; \mathrm{R} 2=.318)$ and the skills of modelling the way, inspiring a shared vision and enabling personnel to act explains $32.5 \%$ of the competency of knowledge 
creation $(\mathrm{R}=.57 ; \mathrm{R} 2=.325)$.

Table 6. Stepwise multiple regression analysis results concerning the prediction of knowledge management process competency of knowledge acquisition

\begin{tabular}{|c|c|c|c|c|c|c|c|c|c|c|}
\hline$\frac{\bar{d}}{\frac{c}{c}}$ & $\frac{\frac{0}{0}}{\frac{\pi}{\pi}}$ & B & $\mathrm{SH}_{\mathrm{B}}$ & $\beta$ & $\mathrm{t}$ & $\mathrm{p}$ & $\mathrm{R}$ & $\mathrm{R}^{2}$ & $\mathrm{~F}$ & $\mathrm{p}$ \\
\hline \multirow[t]{2}{*}{1} & Constant & 13.124 & 1.091 & & 12.030 & .000 & .453 & .205 & 147.661 & .000 \\
\hline & $\begin{array}{l}\text { Inspiring a } \\
\text { shared } \\
\text { vision }\end{array}$ & .568 & .047 & .453 & 12.152 & .000 & & & & \\
\hline \multirow[t]{3}{*}{2} & Constant & 12.436 & 1.120 & & 11.107 & .000 & .463 & .214 & 77.697 & .000 \\
\hline & $\begin{array}{l}\text { Inspiring a } \\
\text { shared } \\
\text { vision }\end{array}$ & .389 & .085 & .310 & 4.571 & .000 & & & & \\
\hline & $\begin{array}{l}\text { Enabling } \\
\text { personnel } \\
\text { to act }\end{array}$ & .210 & .083 & .171 & 2.520 & .012 & & & & \\
\hline
\end{tabular}

As seen in Table 6, two models emerged as a result of the analysis. In the first model, the leadership skill of inspiring a shared vision $(\beta=.453 ; \mathrm{t}=12.152 ; \mathrm{p}<.001)$ predicts the competency of knowledge acquisition. In the second model, in addition to the leadership skill of inspiring a shared vision $(\beta=.31 ; \mathrm{t}=4.571 ; \mathrm{p}<.001)$, enabling personnel to act $(\beta=.171 ; \mathrm{t}$ $=2.520 ; \mathrm{p}<.05)$ is among the variables that predict the competency of knowledge acquisition. As the second model, which has higher explanation rate of variance in the competency of knowledge acquisition than the first model, is taken into account, the level of importance of predictor variables over the competency of knowledge acquisition was found as inspiring a shared vision $(\beta=.31)$ and enabling personnel to act $(\beta=.171)$, respectively. Inspiring a shared vision alone explains $20.5 \%$ of the competency of knowledge creation $(\mathrm{R}=.453 ; \mathrm{R} 2$ $=.205$ ) whereas inspiring a shared vision and enabling personnel to act together explain $21.4 \%$ of the competency of knowledge acquisition $(\mathrm{R}=.463$; $\mathrm{R} 2=.214)$.

Table 7. Stepwise multiple regression analysis results concerning the prediction of knowledge management process competency of storage and protection of knowledge

\begin{tabular}{|c|c|c|c|c|c|c|c|c|c|c|}
\hline $\begin{array}{l}\overline{0} \\
\bar{\delta} \\
\Sigma\end{array}$ & $\begin{array}{l}\frac{0}{0} \\
\frac{\pi}{0} \\
\frac{\pi}{\pi} \\
j\end{array}$ & B & $\mathrm{SH}_{\mathrm{B}}$ & $\beta$ & $\mathrm{t}$ & $\mathrm{p}$ & $\mathrm{R}$ & $\mathrm{R}^{2}$ & $\mathrm{~F}$ & $\mathrm{p}$ \\
\hline \multirow[t]{2}{*}{1} & Constant & 31.636 & 1.648 & & 19.194 & .000 & .391 & .153 & 103.124 & .000 \\
\hline & $\begin{array}{l}\text { Inspiring } \\
\text { a shared } \\
\text { vision }\end{array}$ & .717 & .071 & .391 & 10.155 & .000 & & & & \\
\hline
\end{tabular}


As seen in Table 7 only one model emerged as a result of the analysis. The skill of inspiring a shared vision $(\beta=.391 ; \mathrm{t}=10.155 ; \mathrm{p}<.001)$ predicts the competency of storage and protection of knowledge. The skill of inspiring a shared vision alone explains $15.3 \%$ of the competency of storage and protection of knowledge $(\mathrm{R}=.391$; $\mathrm{R} 2=.153)$.

Table 8. Stepwise multiple regression analysis results concerning the prediction of knowledge management process competency of sharing knowledge

\begin{tabular}{|c|c|c|c|c|c|c|c|c|c|c|}
\hline$\frac{\overline{0}}{\dot{\delta}}$ & $\frac{0}{\frac{0}{0}}$ & B & $\mathrm{SH}_{\mathrm{B}}$ & $\beta$ & $\mathrm{t}$ & $\mathrm{p}$ & $\mathrm{R}$ & $\mathrm{R}^{2}$ & $\mathrm{~F}$ & $\mathrm{p}$ \\
\hline \multirow[t]{2}{*}{1} & Constant & 18.845 & 2.008 & & 9.383 & .000 & .490 & .240 & 180.443 & .000 \\
\hline & $\begin{array}{l}\text { Challenging } \\
\text { the process }\end{array}$ & 1.191 & .089 & .490 & 13.433 & .000 & & & & \\
\hline \multirow[t]{3}{*}{2} & Constant & 17.084 & 2.126 & & 8.038 & .000 & .498 & .248 & 93.994 & .000 \\
\hline & $\begin{array}{l}\text { Challenging } \\
\text { the process }\end{array}$ & .864 & .160 & .356 & 5.394 & .000 & & & & \\
\hline & $\begin{array}{l}\text { Enabling } \\
\text { personnel to } \\
\text { act }\end{array}$ & .395 & .162 & .161 & 2.444 & .015 & & & & \\
\hline
\end{tabular}

As seen in Table 8 two models emerged as a result of the analysis. In the first model the skill of challenging the process $(\beta=.490 ; \mathrm{t}=13.433 ; \mathrm{p}<.001)$ predicts the competency of sharing knowledge. In the second model, in addition to the skill of challenging the process $(\beta=.356$; $t$ $=5.394 ; \mathrm{p}<.001)$ the skill of enabling personnel to act $(\beta=.161 ; \mathrm{t}=2.444 ; \mathrm{p}<.05)$ is among the variables that predicts the competency of sharing knowledge. As the second model, which has a higher explanation rate of the variance in the competency of sharing knowledge, is taken into account the level of importance of predictor variables over the competency of sharing knowledge was found as challenging the process $(\beta=.356)$ and enabling personnel to act ( $\beta$ $=.161$ ), respectively. The skill of challenging the process alone explains $24 \%$ of the competency of sharing knowledge $(\mathrm{R}=.49 ; \mathrm{R} 2=.24)$ whereas the skills of challenging the process and enabling personnel to act together explain $24.8 \%$ of the competency of sharing knowledge $(\mathrm{R}=.498 ; \mathrm{R} 2=.248)$. 
Table 9. Stepwise multiple regression analysis results concerning the prediction of knowledge management process competency of utilization and evaluation of knowledge

\begin{tabular}{|c|c|c|c|c|c|c|c|c|c|c|}
\hline$\frac{\bar{g}}{\bar{c}}$ & $\frac{\frac{0}{0}}{\frac{\pi}{\pi}}$ & B & $\mathrm{SH}_{\mathrm{B}}$ & $\beta$ & $\mathrm{t}$ & $\mathrm{p}$ & $\mathrm{R}$ & $\mathrm{R}^{2}$ & $\mathrm{~F}$ & $\mathrm{p}$ \\
\hline \multirow[t]{2}{*}{1} & Constant & 25.437 & 2.061 & & 12.339 & .000 & .501 & .251 & 191.318 & .000 \\
\hline & $\begin{array}{l}\text { Inspiring } \\
\text { a shared } \\
\text { vision }\end{array}$ & 1.222 & .088 & .501 & 13.832 & .000 & & & & \\
\hline \multirow[t]{3}{*}{2} & Constant & 23.662 & 2.106 & & 11.238 & .000 & .516 & .266 & 103.474 & .000 \\
\hline & $\begin{array}{l}\text { Inspiring } \\
\text { a shared } \\
\text { vision }\end{array}$ & .759 & .160 & .311 & 4.747 & .000 & & & & \\
\hline & $\begin{array}{l}\text { Enabling } \\
\text { personnel } \\
\text { to act }\end{array}$ & .543 & .157 & .227 & 3.458 & .001 & & & & \\
\hline
\end{tabular}

As seen in Table 9, two different models emerged as a result of the analysis. In the first model, the leadership skill of inspiring a shared vision $(\beta=.501 ; \mathrm{t}=13.832 ; \mathrm{p}<.001)$ predicts the competency of utilization and evaluation of knowledge. In the second model, in addition to the leadership skill of inspiring a shared vision $(\beta=.311 ; \mathrm{t}=4.747 ; \mathrm{p}<.001)$ the skill of enabling personnel to act $(\beta=.227 ; \mathrm{t}=3.458 ; \mathrm{p}<.01)$ is among the variables that predict the competency of sharing knowledge. As the second model, which has a higher explanation rate of the variance in the competency of utilization and evaluation of knowledge, is taken into account the level of importance of predictor variables over the competency of utilization and evaluation of knowledge was found as inspiring a shared vision $(\beta=.311)$ and enabling personnel to act $(\beta=.227)$, respectively. The skill of inspiring a shared vision alone explains $25.1 \%$ of the competency of sharing knowledge $(\mathrm{R}=.501 ; \mathrm{R} 2=.251)$ and the skills of inspiring a shared vision and enabling personnel to act together explain $26.6 \%$ of the competency of utilization and evaluation of knowledge $(\mathrm{R}=.516 ; \mathrm{R} 2=.266)$.

\section{Discussion, Conclusion and Suggestions}

Leadership has an important role in the creation and management of knowledge. In successful realization of knowledge, creation and management leadership practices have a catalyst effect (Singh, 2008). Knowledge management can affect leadership practices. Knowledge management can promote the connections and relationships among employees. The promotion of employees to cooperate and share knowledge by the knowledge management process is effective in leadership practices. The application of knowledge management helps leaders to use their time more effectively and promotes innovative practices within the organization (Fleenor \& Rego, 2005).

In this study it was determined that knowledge management process competencies are related 
to leadership skills. In parallel with this finding, Babu et al. (2008) reported a positive relationship between leadership skill and knowledge management in their study in which they investigated the relationship between leadership skills and knowledge management. Similarly, there are number of studies stating that leadership has an important role in knowledge management. In his study performed to determine whether knowledge management is successfully applied in primary and secondary schools and to determine the problems encountered in knowledge management process Leung (2010) stated that leadership is at the top among other critical success factors. Moreover, he reported that the leadership, the top factor in the realization of knowledge management in schools, can initiate the knowledge sharing process. Mason and Pauleen (2003) ascertained that 23\% of the obstacles to knowledge management practice are related to leadership and $33 \%$ of the most important factors in knowledge management practice are leadership and motivation.

In their study performed to determine teachers' perceptions on school leaders' attitudes in relation to knowledge management, Celep and Çetin (2005) reported that leadership is among the sub-dimensions of knowledge management. Ípçioğlu (2004), in his study which investigates the relationship between leadership and knowledge management, determined a statistically significant and a very strong positive relationship between knowledge leadership and utilization of knowledge. In his study investigating whether there is a relationship between the benefits of knowledge management practices and leadership roles, Kılıç (2006) reported a positive relationship between the roles of leaders related to continuing and supporting knowledge management and their roles in the utilization and sharing of knowledge. In a qualitative study performed in two primary schools, Barlow (2008) investigated organizational learning and knowledge management in relation to the promotion and application of learning communities. In the study, the ideal properties of organizational learning, knowledge management and professional learning communities were determined depending on the fundamental stages of knowledge preparation, acquisition, assimilation and application. Executive support in the context of knowledge preparation stage and supportive leadership in the context of knowledge assimilation stage were determined among the properties of organizational learning, knowledge management and professional learning communities.

Leadership skills are an important necessity to realize knowledge management effectively. The relationships between leadership skills and knowledge management process competencies that emerged in this study also revealed the importance of leadership for knowledge management. The improvement of school principals' leadership skills is essential for the application of knowledge management in schools. School principals, by their positions, are the most important persons who can provide the practice of knowledge management in schools. However, executive roles and skills alone are not adequate for school principals to realize knowledge management. It is necessary for school principals to have leadership skills and to exhibit these skills by attitudes. There are studies concerning the fact that leadership skills can be improved. In their studies in which the differences in leadership skills during different stages were investigated, Mumford et al. (2000) concluded that a well-designed education can contribute to the improvement of leadership skills. Saremba (2002) performed 
a study in which school principals and assistant principals participated to determine the resources that can be created and applied for the purpose of promoting the leadership skills of school executives. According to the results of this study, school executives believe that leadership skills can be taught. Therefore, school principals should reinforce knowledge management process competencies and provide effective application of knowledge management in schools by accepting leadership roles as well as executive roles and by attempting to promote their leadership skills.

In accordance with the results of the study, the suggestions below can be offered:

1. School principals, by applying knowledge management process competencies and leadership skills together, should take the knowledge leader role in schools. For this, in-service training programs should be designed for the consistent utilization of knowledge management process competencies and leadership skills and school principals should be encouraged to participate in such programs.

2. A hands-on training program can be prepared to improve school principals' leadership skills and knowledge management process competencies together and to provide the realization of knowledge management in schools. This program, to be run with the intense cooperation of school principals and researchers, can be designed as a three stage-program containing the stages of preparation, knowledge management practice, and evaluation of knowledge management practice.

3. Whether the relationship between school principals' leadership skills and knowledge management process competencies and the level at which to predict knowledge management process competencies show differences at different educational levels can be investigated as well as investigating the reasons for potential differences.

\section{References}

Alazmi, M., \& Zairi, M. (2003). Knowledge management critical success factors. Total Quality $\begin{array}{llll}\text { Management } \quad \& \quad \text { Business } \quad \text { Excellence, } & 14(2),\end{array}$ http://dx.doi.org/10.1080/1478336032000051386

Arntzen, A.A.B., \& Chumnumpan, P. (2010). Investigation of knowledge sharing practices among expatriates in Thailand. In: $11^{\text {th }}$ European conference on knowledge management, Portugal, 2-3 September 2010, pp.82-89.

Babu, G.S., Rao, T.M., Ahmed, S., \& Gupta, K.S. (2008). Relationship between leadership capability and knowledge management: A measurement approach. Journal of Information \& Knowledge Management, 7(2), 83-92. http://dx.doi.org/10.1142/S0219649208001968

Barlow, S.R. (2008). A study of organizational learning and knowledge management as mechanisms for educational change: The development of professional learning communities in a school district. PhD Thesis, University of California, Riverside. 
Bhatt, G.D. (2001). Knowledge management in organizations: Examining the interaction between technologies, techniques, and people. Journal of Knowledge Management, 5(1), 68-75. http://dx.doi.org/10.1108/13673270110384419

Bourdreau, A., \& Couillard, G. (1999). Systems integration and knowledge management. Information Systems Management, $\quad 16(4), \quad$ 1-9. http://dx.doi.org/10.1201/1078/43189.16.4.19990901/31200.4

Celep, C., \& Çetin, B. (2005). Teachers' perception about the behaviours of school leaders with regard to knowledge management. International Journal of Educational Management, 19(2), 102-117. http://dx.doi.org/10.1108/09513540510582408

Chadha, S.K., \& Kapoor, D. (2010). A study on knowledge management practices of auto component manufacturing companies in Ludhiana city. The IUP Journal of Knowledge Management, 8(1\&2), 68-76.

Charney, C. (2005). Leader's tool kit: Hundreds of tips and techniques for developing the skills you need. Saranac Lake, NY, USA: AMACOM Books.

Darroch, J. (2003). Developing a measure of knowledge management behaviors and practices. Journal of Knowledge Management, $\quad 7(5), \quad$ 41-54. http://dx.doi.org/10.1108/13673270310505377

Davenport, T.H., \& Völpel, S.C. (2001). The rise of knowledge towards attention management. Journal of Knowledge Management, 5(3), 212-221. http://dx.doi.org/10.1108/13673270110400816

DeTienne, K.B., Dyer, G., Hoopes, C., \& Harris, S. (2004). Toward a model of effective knowledge management and directions for future research: Culture, leadership, and CKOs. Journal of Leadership \& Organizational Studies, 10(4), 26-43. http://dx.doi.org/10.1177/107179190401000403

Duygulu, S. (2007). The effects of the transformational leadership (TL) training program on the leadership practices of Unit Charge Nurses (UCN). Unpublished PhD Thesis, Hacettepe University, Ankara, Turkey.

Eppler, M.J., \& Sukowski, O. (2000). Managing team knowledge: Core processes, tools and enabling factors. European Management Journal, 18(3), 334-341. http://dx.doi.org/10.1016/S0263-2373(00)00015-3

Fleenor, J., \& Rego, L. (2005). A question of leadership: How can knowledge management affect the practice of leadership? Leadership in Action, 25(3), 14-15. http://dx.doi.org/10.1002/lia.1117

Greengard, S. (1998). How to make KM a reality. Workforce, 77(10), 90-91.

Güçlü, N., \& Sotirofski, K. (2006). Knowledge management. Journal of Turkish Educational Sciences, 4(4), 351-371. 
Hedlund, G. (1994). A model of knowledge management and the N-form corporation. Strategic Management Journal Summer, 15, 73-90. http://dx.doi.org/10.1002/smj.4250151006

Holsapple, C.W., \& Joshi, K.D. (2002). Knowledge management: A threefold framework. The Information Society, 18(1), 47-64. http://dx.doi.org/10.1080/01972240252818225

Inkpen, A. (1996). Creating knowledge through collaboration. California Management Review 39(1), 123-140. http://dx.doi.org/10.2307/41165879

İpçioğlu, İ. (2004). A study on the examining the effects of leadership and organizational culture on knowledge management in companies. Unpublished $\mathrm{PhD}$ Thesis, Dumlupinar University, Kütahya, Turkey.

Karasar, N. (2011). Scientific research method. (22th edn.). Ankara: Nobel Akademik Publishing.

Kiliç, S. (2006). A study on the role of leadership in knowledge management. Unpublished Master Thesis, Niğde University, Niğde, Turkey.

Koenig, M.E.D. (1999). Education for knowledge management. Information Services \& Use, 19(1), 17-31.

Kouzes, J.M., \& Posner, B.Z. (2001). Leadership practices inventory [LPI]. (Revised second edition, online version, participant's workbook), San Francisco: Jossey-Bass/Pfeiffer. [Online] Available: http://consummatecoaching.com/images/LPI-WB_book.pdf (May 1, 2012).

Lee, H., \& Choi, B. (2003). Knowledge management enablers, processes, and organizational performance: An integrative view and empirical examination. Journal of Management Information Systems, 20(1), 179-228.

Leung, C-H. (2010). Critical factors of implementing knowledge management in school environment: A qualitative study in Hong Kong. Research Journal of Information Technology, 2(2), 66-80. http://dx.doi.org/10.3923/rjit.2010.66.80s

Liebowitz, J. (1999). Key ingredients to the success of an organization's knowledge management strategy. Knowledge and Process Management, 6(1), 37-40. http://dx.doi.org/10.1002/(SICI)1099-1441(199903)6:1<37::AID-KPM40>3.0.CO;2-Ms

Mason, D., \& Pauleen, D.J. (2003). Perceptions of knowledge management: A qualitative analysis. Journal of Knowledge Management, $7(4), \quad 38-48$. http://dx.doi.org/10.1108/13673270310492930

McKenzie, J., Truc, A., \& van Winkelen, C. (2001). Winning commitment for knowledge management initiatives. Journal of Change Management, 2(2), 115-127. http://dx.doi.org/10.1080/714042493

Mumford, M.D., Marks, M.A., Connelly, M.S., Zaccaro, S.J., \& Palmon, R.R. (2000). Development of leadership skills: Experience and timing. Leadership Quarterly, 11(1), 87-114. http://dx.doi.org/10.1016/S1048-9843(99)00044-2 


\section{Macrothink}

Journal of Studies in Education

ISSN 2162-6952

2015, Vol. 5, No. 3

Nielsen, A.P. (2006). Understanding dynamic capabilities through knowledge management. $\begin{array}{llll}\text { Journal of } \quad \text { Knowledge } \quad \text { Management, } & \text { 10(4), }\end{array}$ http://dx.doi.org/10.1108/13673270610679363

O'Brien, J., Murphy, D., \& Draper, J. (2008). School leadership. Edinburgh, GBR: Dunedin Academic Press.

Pimentel, A.C.M., \& Albino, J.P. (2010). An approach for implementing knowledge management in small and medium companies in Brazil: A case study. In: $11^{\text {th }}$ European conference on knowledge management, Portugal, 2-3 September 2010, pp.647-652.

Rastogi, P.N. (2000). Knowledge management and intellectual capital - the new virtuous reality of competitiveness. Human Systems Management, 19(1), 39-48.

Rocha, F.S., Cardoso, L., \& Tordera, N. (2008). The importance of organizational commitment to knowledge management. Comportamento Organizacional e Gestão, 14(2), 211-232.

Santo, S.A. (2005). Knowledge management: An imperative for schools of education. TechTrends, 49(6), 42-49. http://dx.doi.org/10.1007/BF02763729

Saremba, A.M. (2002). Implementing and creating resources to develop effective leadership skills in school-based administrators. Unpublished Master Thesis, Royal Roads University.

Singh, S.K. (2008). Role of leadership in knowledge management: A study. Journal of Knowledge Management, 12(4), 3-15. http://dx.doi.org/10.1108/13673270810884219

Tranfield, D., Young, M., \& Partington, D. (2003). Knowledge management routines for innovation projects: Developing a hierarchical process model. International Journal of Innovation Management, 7(1), 27-49.

http://dx.doi.org/10.1142/S1363919603000726

Turner, G., \& Minonne, C. (2010). Measuring the effects of knowledge management practices. Electronic Journal of Knowledge Management, 8(1), 161-170.

Valenzuela, M.B., \& Schmitz, G.S. (2010). Knowledge management opportunity space identification strategy. Knowledge and Process Management, 17(3), 111-117. http://dx.doi.org/10.1002/kpm.348

Vorakulpipat, C., \& Rezgui, Y. (2008). An evolutionary and interpretive perspective to knowledge management. Journal of Knowledge Management, 12(3), 17-34. http://dx.doi.org/10.1108/136732708108758318

Zack, M.H. (1999). Managing codified knowledge. Sloan Management Review, 40(4), 45-58. 